\title{
Production and Regeneration of Protoplasts from Orchid Mycorrhizal Fungi Epulorhiza repens and Ceratorhiza sp.
}

\author{
Irene da Silva Coelho, Marisa Vieira de Queiroz, Maurício Dutra Costa, Maria Catarina \\ Megumi Kasuya and Elza Fernandes de Araújo \\ Departamento de Microbiologia; Universidade Federal de Viçosa; 36570-000; Viçosa - MG - Brasil
}

\begin{abstract}
The aim of this work was to study the standardization of conditions to obtain and regenerate Epulorhiza repens and Ceratorhiza sp. protoplasts. For E. repens, the largest number of protoplasts $\left(8.0 \times 10^{6}\right.$ protoplasts $\left./ \mathrm{mL}\right)$ was obtained in $0.6 \mathrm{M} \mathrm{KCl}$, using $15 \mathrm{mg} / \mathrm{mL}$ of Lysing Enzymes, and 2-day-old fungal mycelium. When $0.5 \mathrm{M}$ sucrose was used as osmotic stabilizer, the highest frequency of regeneration was achieved (8.5\%); $80.0 \%$ of protoplasts were nucleated, and $20.0 \%$ anucleated. For Ceratorhiza sp., the largest number of protoplasts $\left(4.0 \times 10^{7}\right.$ protoplasts $(\mathrm{mL}$ ) was achieved in $0.6 \mathrm{M} \mathrm{NaCl}$, when $15 \mathrm{mg} / \mathrm{mL}$ of Lysing Enzymes and $15 \mathrm{mg} / \mathrm{mL}$ of Glucanex, with 2day-old fungal mycelium were used. The highest frequency of regeneration was $6.7 \%$ using $0.5 \mathrm{M}$ sucrose as osmotic stabilizer; $88.8 \%$ of protoplasts were nucleated, and $11.2 \%$ anucleated.
\end{abstract}

Key words: Ceratorhiza, Epulorhiza, molecular biology, protoplast, regeneration

\section{INTRODUCTION}

In nature, orchids are associated with mycorrhizal fungi for seed germination and plant nutrition to ensure to complete plant life cycle (Peterson et al., 1998). Orchids make use of intracellularly formed masses of hyphae (pelotons), present mainly in root cortex cells, as a carbon source during the heterotrophic stage of their lives (Peterson et al., 1998). Orchid mycorrhizal fungi have been isolated from their natural hosts and used to improve in vitro seed germination and produce seedlings of endangered species to be reintroduce in their natural habitat (Zettler, 1997; Zettler et al., 2000; Pereira et al., 2003), or to multiply the species of ornamental (Zettler et al., 1999) and medicinal (Chang and Chou, 2001) interest.
Although these fungi present a biotechnological potential, little is known about their physiology and genetic. Establishing an effective protocol to obtain and regenerate protoplasts of orchid mycorrhizal fungi is important for determining their electrophoretic karyotype and for works involving transformation and functional analyses of genes related to fungus-plant interaction.

Knowing which factors affect the protoplast production is essential to optimize the conditions for protoplasts release and regeneration for each fungal species (Kumari and Panda, 1992). Factors such as age and quantity of mycelium, osmotic stabilizer, temperature, $\mathrm{pH}$, digestion time, and lytic enzyme concentration are mentioned as determinants of success (Peberdy et al., 1976; Chadegani et al., 1989). It is also important to

*Author for correspondence: ezfa@ufv.br 
ensure protoplast regeneration, which consists of cell wall reconstitution and return to mycelial growth. Fungal growth tests at different concentrations of osmotic stabilizers are necessary since high solute concentrations often inhibit the fungal growth. Regeneration frequency obtained for different fungi ranges from 0.1 to $50.0 \%$, depending, mainly, on fungal species, cell ploidy, and regeneration medium (Peberdy, 1991).

Some protocols for obtaining and regenerating the protoplasts have already been established for some Basidiomycetes species, such as Rhizoctonia solani (Hashiba and Yamada, 1982), Agaricus bisporus (Royer et al., 1992), Suillus granulatus (Dias et al., 1996), Pseudozyma flocculosa (Cheng and Bélanger, 2000), Lentinus lepideus (Kim et al., 2000), Crinipellis perniciosa (Lima et al., 2003) and Stropharia rugoso-anulata (Yan et al., 2004).

This work aimed at establishing the conditions for production and regeneration of protoplasts of Epulorhiza repens and Ceratorhiza sp.

\section{MATERIALS AND METHODS}

\section{Microorganisms and growth conditions}

Orchid mycorrhizal fungi isolates from Brazilian native orchids, Epulorhiza repens (VIC 27806) and Ceratorhiza sp. (VIC 27808) (Pereira et al., 2005) belonging to "Laboratório de Associações Micorrízicas, Departamento de Microbiologia/BIOAGRO, Universidade Federal de Viçosa/MG/Brazil" were used. Fungal cultures were maintained at $25^{\circ} \mathrm{C}$ in solid modified Melin Norkrans (MMN) medium (Marx, 1969).

\section{Protoplasts production}

Three hundred milligrams of mycelium, slightly dried in gauze and toilet paper, were transferred to $50-\mathrm{mL}$ Erlenmeyer flasks containing $5 \mathrm{~mL}$ of osmotic stabilizer and different amounts of hydrolytic enzymes. This hydrolytic preparation was incubated at $30{ }^{\circ} \mathrm{C}$ and $80 \mathrm{rpm}$ from 1 to $24 \mathrm{~h}$. Protoplast countings were carried out using a Neubauer chamber in a microscope.

Both fungi mycelium were grown by inoculating 4 agar discs, cut off from the edge of colonies cultivated for 10 days at $25^{\circ} \mathrm{C}$ in solid MNM into Petri dishes containing $20 \mathrm{~mL}$ of liquid MNM medium, and then incubated at $25^{\circ} \mathrm{C}$ for 2 and 4 days, respectively for Ceratorhiza sp. and $E$. repens. For protoplast production, Ceratorhiza sp. mycelium was directly used while E. repens mycelium was fragmented in a blender by applying two pulses of 2 seconds each, and aliquots of mycelial suspension were inoculated into $100 \mathrm{~mL}$ of MMN medium and incubated at 25 ${ }^{\circ} \mathrm{C}$ for 2 days at $150 \mathrm{rpm}$.

The osmotic stabilizers mannitol, $\mathrm{KCl}, \mathrm{NaCl}$ and $\mathrm{MgSO}_{4}$ were tested at the following concentrations $0.6 ; 0.8 ; 1.0$ and $1.2 \mathrm{M}$. The lytic enzymes, Glucanex (Novo Nordish Ferment Ltd., CH4243), Lysing Enzymes (Sigma Chemical Co., L1412), and Cellulase (Sigma Chemical Co., C8546), were also tested individually or in combination. Cellulase was used at $20 \mathrm{mg} / \mathrm{mL}$ and Lyzing Enzymes and Glucanex at $15 \mathrm{mg} / \mathrm{mL}$.

\section{Protoplast Regeneration}

After digestion, the hydrolytic preparations were filtered with gauze to retain the hyphal fragments. The filtrate, containing the hydrolytic preparation and protoplasts, was centrifuged at $710 \mathrm{~g}$ for 10 minutes. The sediment was resuspended in $5 \mathrm{~mL}$ of osmotic stabilizer, centrifuged again and resuspended in $1 \mathrm{~mL}$ of the same medium. Protoplasts were counted in a Neubauer chamber. Protoplasts were transferred by the "pour plate" technique to MMN medium containing osmotic stabilizers (sucrose, mannitol, $\mathrm{KCl}$ and $\mathrm{NaCl}$, at 0.5 or $1.0 \mathrm{M}$ ). A control was done in $\mathrm{MMN}$ medium, with no osmotic stabilizer, to calculate the regeneration frequency. Plates were incubated at $25^{\circ} \mathrm{C}$ until colonies formation on the surface of the medium.

All experiments were done twice and the results represent the mean of two repetitions.

\section{Protoplast nuclei staining}

To determine the percentage of nucleated protoplasts, a droplet of the protoplast suspension was spread on a slide glass and dried at room temperature, then placed in methanol for 5 minutes and washed three times with $100 \mathrm{mM} \mathrm{KH}_{2} \mathrm{PO}_{4}, \mathrm{pH}$ 7.0. After drying, $15 \mu \mathrm{L}$ of a solution containing 1 $\mu \mathrm{L} / \mathrm{mL}$ of SYBR Green I 10.000 X (Sigma Sigma Chemical Co., S9430) was used for nuclei staining (Meinhardt et al., 2001). After 5 minutes of contact with the dye solution, the protoplasts were observed in a Nikon E600 microscope with a YFL epi-fluorescence attachment, excitation wavelength range of $450-520 \mathrm{~nm}$. Images were captured using a Fuji HC-300Z digital camera and processed with Photograb and Eztouch (Fujifilm). For both the fungal species, 150 protoplasts were observed. 


\section{RESULTS AND DISCUSSION}

$\mathrm{KCl}$ at $0.6 \mathrm{M}$ provided the highest protoplast release for E. repens $\left(2.0 \times 10^{4}\right.$ protoplasts $\left./ \mathrm{mL}\right)$ (Table 1). Low protoplast yields, in the order of $10^{4}$ protoplasts $/ \mathrm{mL}$, obtained for the different stabilizer suggested that Glucanex was not appropriate for E. repens. For Ceratorhiza sp., 0.6 $\mathrm{M} \mathrm{NaCl}$ was selected since $4.1 \times 10^{5}$ protoplasts $/ \mathrm{mL}$ were released and greater protoplast stability was observed when this stabilizer was used (Table 1). Choosing the osmotic stabilizer and its concentration is an important feature to be considered when isolating protoplasts. The best osmotic stabilizer varies for each type of microorganism and its ideal concentration is related to differences in internal osmotic pressure in the cells (Villanueva and Acha, 1971). For Suillus granulatus, the stabilizer which allowed the largest protoplast release was $0.7 \mathrm{M} \mathrm{MgSO}_{4}$, for Agaricus bisporus, $0.8 \mathrm{M}$ $\mathrm{MgSO}_{4}$, and for $C$. perniciosa, $0.6 \mathrm{M} \mathrm{KCl}$ (Royer et al., 1992; Dias et al., 1996; Lima et al., 2003).

Table 1 - E. repens and Ceratorhiza sp. protoplast production in media with different osmotic stabilizers, after a 5-h treatment with hydrolytic preparation.

\begin{tabular}{lcc}
\hline \multirow{2}{*}{ Osmotic stabilizers } & E. repens & Ceratorhiza sp. \\
\cline { 2 - 3 } & \multicolumn{2}{c}{ Protoplasts/mL } \\
\hline Mannitol 0.6 M & 0 & $1.5 \times 10^{5}$ \\
Mannitol 0.8 M & 0 & $2.0 \times 10^{5}$ \\
Mannitol 1.0 M & 0 & $5.0 \times 10^{4}$ \\
$\mathrm{KCl} 0.6 \mathrm{M}$ & 0 & $3.5 \times 10^{4}$ \\
$\mathrm{KCl} 0.8 \mathrm{M}$ & $2.0 \times 10^{4}$ & $1.3 \times 10^{5}$ \\
$\mathrm{KCl} 1.0 \mathrm{M}$ & $1.5 \times 10^{4}$ & $9.0 \times 10^{4}$ \\
$\mathrm{KCl} \mathrm{1.2} \mathrm{M}$ & 0 & $3.0 \times 10^{4}$ \\
$\mathrm{NaCl} \mathrm{0.6} \mathrm{M}$ & 0 & $1.5 \times 10^{4}$ \\
$\mathrm{NaCl} \mathrm{0.8} \mathrm{M}$ & 0 & $4.1 \times 10^{5}$ \\
$\mathrm{NaCl} \mathrm{1.0} \mathrm{M}$ & $1.0 \times 10^{4}$ & $1.2 \times 10^{5}$ \\
$\mathrm{NaCl} \mathrm{1.2} \mathrm{M}_{\mathrm{MgSO}} 0.6 \mathrm{M}$ & 0 & $3.5 \times 10^{4}$ \\
$\mathrm{MgSO}_{4} 0.8 \mathrm{M}$ & 0 & $1.5 \times 10^{4}$ \\
$\mathrm{MgSO}_{4} 1.0 \mathrm{M}$ & $1.0 \times 10^{4}$ & $6.5 \times 10^{4}$ \\
$\mathrm{MgSO}_{1.2 \mathrm{M}}$ & 0 & $5.0 \times 10^{4}$ \\
\hline
\end{tabular}

In all tests, $300 \mathrm{mg}$ of mycelium was treated with $15 \mathrm{mg} / \mathrm{mL}$ de Glucanex.

Cell wall composition varies among organisms, and it is assumed that enzyme preparations should be optimized for each species. For E. repens, when Lysing Enzymes were used, $1.0 \times 10^{6}$ protoplasts $/ \mathrm{mL}$ were obtained after a 24-h digestion, while for Ceratorhiza sp., the best result $\left(1.6 \times 10^{6}\right.$ protoplasts $\left./ \mathrm{mL}\right)$, with a 5 -h digestion, occurred when a combination of Glucanex and Lysing Enzymes was used (Table 2).

Different lytic enzymes have been used alone or in combinations and in different amounts for cell wall digestion. An important characteristic of these commercial preparations is that they are complex compounds of several hydrolytic enzymes. For instance, enzymes obtained from Trichoderma harzianum have $\alpha$-glucanase, $\beta$-glucanase, and chitinase activities (Kelkar et al., 1990; Kavanagh and Whittaker, 1996). Larger amounts of protoplasts were obtained from Rhizoctonia solani when an enzyme combination (Cellulase Onozuka R-10, Macerozyme R-10 from Rhizopus sp., and $\beta$-glucuronidase from Helix pomatia digestive juice) was used (Hashiba and Yamada, 1982). For Suillus granulatus and Agaricus bisporus, the best enzyme was Novozym 234 (Royer et al. 1992; Dias et al., 1996). Glucanex was the most appropriate enzyme for Crinipellis perniciosa (Lima et al., 2003).

Mycelium age is regarded as one of the main factors which influence the protoplast release (Gold et al., 1983; Peberdy et al., 1976). Although mycelium cultivation time that allows best protoplast release vary for each species, optimal cultivation time for Ceratorhiza sp. and E. repens protoplasts was two days (Table 3). 
Table 2 - E. repens and Ceratorhiza sp. protoplast production in media with different enzyme preparations after different times of treatment with hydrolytic preparations.

\begin{tabular}{lccc}
\hline \multirow{2}{*}{ Enzymes } & $\begin{array}{c}\text { E. repens } \\
\mathbf{( 5 ~ h s )}\end{array}$ & $\begin{array}{c}\text { E. repens } \\
\mathbf{( 2 4} \mathbf{~ h s})\end{array}$ & $\begin{array}{c}\text { Ceratorhiza sp. } \\
(\mathbf{5} \text { hs })\end{array}$ \\
\cline { 2 - 4 } & & Protoplasts/mL & $1.5 \times 10^{5}$ \\
\hline Glucanex & $6.0 \times 10^{5}$ & $5.3 \times 10^{5}$ & 0 \\
Cellulase & $2.0 \times 10^{4}$ & $8.0 \times 10^{4}$ & $2.0 \times 10^{5}$ \\
Lysing Enzymes & $8.4 \times 10^{5}$ & $1.0 \times 10^{6}$ & $2.7 \times 10^{5}$ \\
Glucanex + Cellulase & $5.0 \times 10^{4}$ & $1.7 \times 10^{5}$ & $1.6 \times 10^{6}$ \\
Glucanex + Lysing Enzymes & $5.8 \times 10^{5}$ & $3.2 \times 10^{5}$ & $5.8 \times 10^{5}$ \\
Cellulase + Lysing Enzymes & $5.0 \times 10^{4}$ & $1.0 \times 10^{4}$ & $\mathrm{NT}$ \\
Glucanex + Cellulase + Lysing Enzymes & $1.8 \times 10^{5}$ & $3.0 \times 10^{5}$ & $\mathrm{~N}$
\end{tabular}

In all tests, $300 \mathrm{mg}$ of mycelium was used. For Epulorhiza repens $0.6 \mathrm{M} \mathrm{KCl}$ and for Ceratorhiza sp. $0.6 \mathrm{M} \mathrm{NaCl}$ were used as osmotic estabilizers. NT not tested.

Table 3 - E. repens and Ceratorhiza sp. protoplast production from mycelia cultivated during different periods of time, after a 5-h treatment with hydrolytic preparation.

\begin{tabular}{ccc}
\hline \multirow{2}{*}{$\begin{array}{c}\text { Cultivation time } \\
\text { (Days) }\end{array}$} & E. repens & Ceratorhiza sp. \\
\cline { 2 - 3 } & \multicolumn{2}{c}{ Protoplasts/mL } \\
\hline 1 & 0 & $3.3 \times 10^{5}$ \\
3 & $1.9 \times 10^{6}$ & $1.7 \times 10^{6}$ \\
3 & $4.0 \times 10^{5}$ & $9.0 \times 10^{5}$
\end{tabular}

In all tests, $300 \mathrm{mg}$ of mycelium was used. For Epulorhiza repens $0.6 \mathrm{M} \mathrm{KCl}$ and Lysing Enzymes and for Ceratorhiza sp. $0.6 \mathrm{M}$ $\mathrm{NaCl}$ and the combination of Lysing Enzymes and Glucanex were used.

Fungi with very high growth rates present a mycelium that is more susceptible to degradation than that of those with slower growth rate, allowing a greater protoplast release within less than $24 \mathrm{~h}$ of cultivation (Hashiba and Yamada,
1982). Although Ceratorrhiza used to have faster growth than Epulorrhiza, this characteristic didn't affect the mycelial degradation, but the number of protoplasts was higher to Ceratorhiza sp. (Fig. 1).

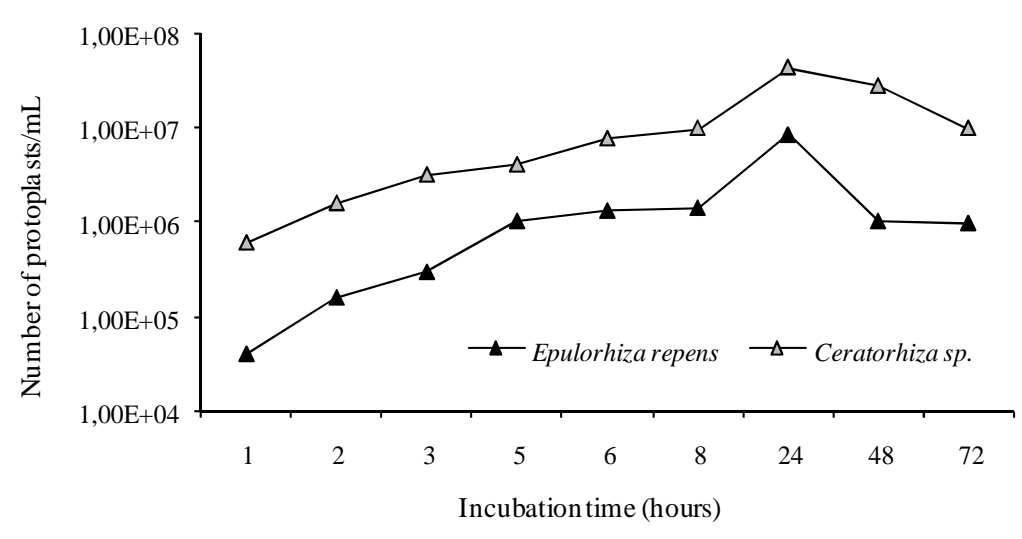

Figure 1 - Number of protoplasts of E. repens and Ceratorhiza sp. produced during incubation of $500 \mathrm{mg}$ of 2-day-old fungal mycelium in hydrolytic preparations for $72 \mathrm{~h}$. For $E$. repens $0.6 \mathrm{M} \mathrm{KCl}$ containg Lysing Enzymes and for Ceratorhiza sp., $0.6 \mathrm{M} \mathrm{NaCl}$ and a combination of Glucanex and Lysing Enzymes were used. 
Incubation time must be considered during protoplast release, since the length of contact with lytic enzymes may lead to disrupture of the first protoplasts formed (Kim et al., 2000). For E. repens and Ceratorhiza sp., the largest protoplasts number was obtained after a 24-h incubation (Fig. $1)$. Under this condition protoplast yields for $E$. repens and Ceratorhiza sp. were $8.0 \times 10^{6}$ and 4.0 $\times 10^{7}$ protoplasts $/ \mathrm{mL}$, respectively (Fig. 1). Longer treatments, exceeding $24 \mathrm{~h}$, did not improve yields. Long incubation of digestion mixtures has been related to lyse protoplasts (Chadegani et al., 1989), while other researchers have suggested that a longer time of incubation is more favorable (Toyama et al., 1984; Kolar et al., 1985; Laurila et al., 1985).

Cell wall regeneration and reversion to normal cells is an important step in genetic manipulation of fungi (Peberdy, 1989). For both studied fungi, the best stabilizer was $0.5 \mathrm{M}$ sucrose with regeneration percentages of 8.5 and $6.7 \%$, respectively (Fig. 2). The stabilizers varied with the fungi and, for Rhizoctonia solani, the highest frequency $(90.0 \%)$ was obtained with the use of 1.0 M mannitol (Yang et al., 1993), for Suillus granulatus, $8.0 \%$ when used $0.6 \mathrm{M} \mathrm{MgSO}_{4}$ added to MMN medium (Dias et al., 1996), for $C$. perniciosa, was $0.5 \mathrm{M}$ sucrose (Lima et al., 2003). With few exceptions, protoplast regeneration frequency for filamentous fungi varies from 0.1 to $50.0 \%$ (Peberdy, 1991). Low values were found for some Basidiomycetes and could be associated to slower growth in most of these organisms (Peberdy, 1991). Protoplast regeneration for $E$. repens and Ceratorhiza sp. was slow, with the first colonies appearing only after 5 to 7 days of incubation at $25^{\circ} \mathrm{C}$, same time was also required for C. perniciosa (Lima et al., 2003), but in $R$. solani, after 48-72 h, small colonies were observed (Hashiba and Yamada, 1982).

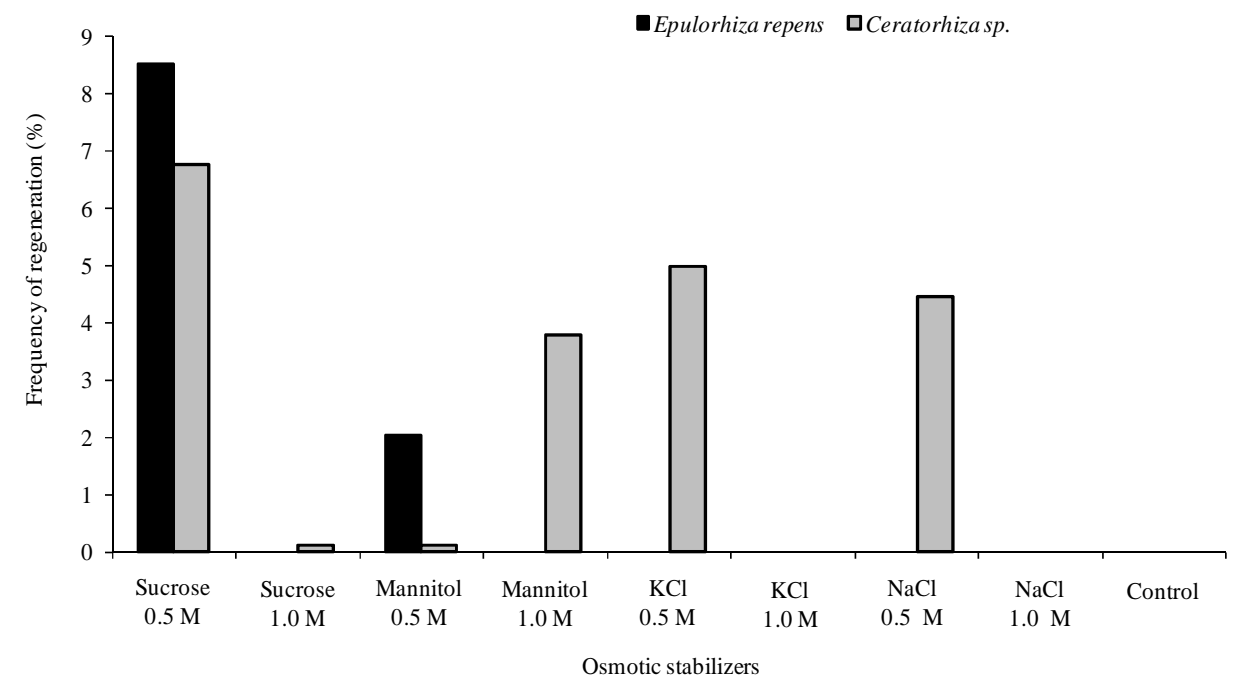

Figure 2 - Frequency of protoplasts regeneration of E. repens and Ceratorhiza sp. in modified Melin Norkrans (MNM) medium with different osmotic stabilizers.

In E. repens protoplast, $58.6 \%$ were uninucleated, $21.4 \%$ binucleate and $20.0 \%$ anucleated, and in Ceratorhiza sp., protoplasts, $61.0 \%$ were uninucleated, $24.6 \%$ binucleate, $3.2 \%$ trinucleate and $11.2 \%$ anucleated (Fig. 3). The absence of nuclei in the protoplast may be one of the factors that influence the regeneration (Peberdy, 1991). The percentage of nucleate protoplasts of $E$. repens and Ceratorhiza sp. was considered high when compared to other Basidiomycetes. At least one nucleus was present in $80 \%$ of the protoplast of E. repens and $88.8 \%$ of Ceratorhiza sp. (Fig. $3)$. So, this was not the main effect in this case. In C. perniciosa, for instance, $58.5 \%$ of protoplasts were anucleated, $37.5 \%$ uninucleated and $3.55 \%$ binucleated (Lima et al., 2003).

Other hypotheses to explain low levels of protoplasts regeneration are protoplasts agglomeration after centrifugation (Deed and Seviour, 1989), high proteolytic activity of the 
enzyme preparations, long exposure of cell wall to lytic enzymes (Hamlyn et al., 1981), and growth conditions (Keller et al., 1983), such as osmotic stabilizer (Solís et al., 1996; Kim et al., 2000), and high concentrations of sugar or salts may affect cell metabolism.

E. repens protoplasts do not regenerate in high concentrations of mannitol and sucrose. In the work of Dias et al. (1996), S. granulatus mycelium was cultivated in medium with different stabilizers. Sucrose, $\mathrm{KCl}$ and $\mathrm{MgSO}_{4}$ provided the best mycelial growth, indicating that they could be used for the production and regeneration of Suillus protoplasts. These stabilizers, in addition to providing osmotic stability, do not cause other changes in cell metabolism (Dias et al., 1996).
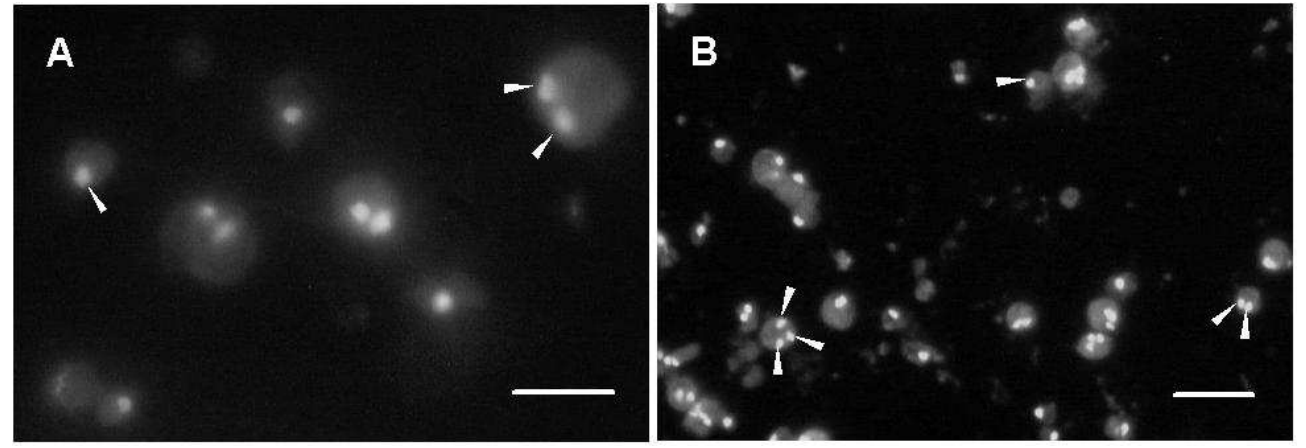

Figure 3 - Nuclei (arrows) in protoplasts of E. repens (A) and Ceratorhiza sp. (B) stained by SYBR Green I observed in a fluorescence microscope with excitation wavelength of 450-520 nm. Bars: (A) $10 \mu \mathrm{m}$, (B) $20 \mu \mathrm{m}$.

\section{ACKNOWLEDGEMENTS}

We thank the Brazilian agencies CNPq (Conselho Nacional de Desenvolvimento Científico e Tecnológico) and FAPEMIG (Fundação de Amparo à Pesquisa do Estado de Minas Gerais) for financial support.

\section{RESUMO}

O objetivo deste trabalho foi padronizar as condições de obtenção e regeneração de protoplastos de Epulorhiza repens e Ceratorhiza sp. Para o fungo E. repens, a maior produção de protoplastos, $8.0 \times 10^{6}$ protoplastos $/ \mathrm{mL}$, foi obtida em $\mathrm{KCl} 0.6 \mathrm{M}$, na presença de $15 \mathrm{mg} / \mathrm{mL}$ de "Lysing Enzymes" e micélio fúngico com 2 dias de idade. A maior freqüência de regeneração obtida foi de $8,5 \%$ quando sacarose $0.5 \mathrm{M}$ foi utilizada como estabilizador osmótico. Do total de protoplastos obtidos, $80 \%$ eram nucleados e $20 \%$ anucleados. Para Ceratorhiza sp., a maior produção de protoplastos, 4,0 $\quad$ x $10^{7}$ protoplastos $/ \mathrm{mL}$, foi obtida em $\mathrm{NaCl} 0.6 \mathrm{M}$, na presença de $15 \mathrm{mg} / \mathrm{mL}$ de "Lysing Enzymes" e $15 \mathrm{mg} / \mathrm{mL}$ de Glucanex, e micélio fúngico com 2 dias de idade. A maior frequiência de regeneração obtida foi de $6.7 \%$ utilizando sacarose $0.5 \mathrm{M}$ como estabilizador osmótico. Do total de protoplastos obtidos, $88.8 \%$ eram nucleados e 1.2 $\%$ anucleados. O estabelecimento de protocolo otimizado para obtenção e regeneração de protoplastos dos fungos E. repens e Ceratorhiza sp. é importante, permitindo o estabelecimento de técnicas de transformação genética, o isolamento de mutantes, a determinação de cariótipo eletroforético e o cruzamento de linhagens.

\section{REFERENCES}

Chadegani, M., Brink, J.J., Shehata, A., Ahmadjan, V. (1989), Optimization of protoplast formation, regeneration, and viability in Microsporum gypseum. Mycopathologia, 107, 33-50

Chang, D.C.N., Chou, L.C. (2001), Seed germination of Haemaria discolor var. dawsoniana and the use of mycorrhizae. Symbiosis, 30, 29-40

Cheng, Y., Bélanger, R.R. (2000), Protoplast preparation and regeneration from spores of biocontrol fungus Pseudozyma flocculosa. FEMS Microbiol. Lett., 190, 287-291

Deed, A., Seviour, R. (1989), Formation and regeneration of protoplasts of Sclerotium glucanicum. Appl. Microbiol. Biotechnol., 31, 259-264

Dias, E.S., Araújo, E.F., Guimarães, W.V., Muchovej, R.M.C. (1996), Production and regeneration of 
protoplasts from the mycorrhizal fungus Suillus granulatus. World. J. Microbiol. Biotechnol., 12, 625-628

Gold, M.H., Cheng, T.M., Alic, M. (1983), Formation, fusion, and regeneration of protoplasts from wildtype and auxotrophic strains of the white rot basidiomycete Phanerochaete chrysosporium. Appl. Environ. Microbiol., 46, 260-263

Hamlyn, P.F., Bradshaw, R.E., Mellon, F.M., Santiago, C.M., Wilson, J.M., Peberdy, J.F. (1981), Efficient protoplast isolation from fungi using commercial enzymes. Enzyme Microb. Technol., 3, 321-325

Hashiba, T., Yamada, M. (1982), Formation and purification of protoplasts from Rhizoctonia solani. Phytopathology, 72, 849-853

Kavanagh, K., Whittaker, P.A. (1996), Application of protoplast fusion to the nonconventional yeast. Enzyme Microb. Technol., 18, 45-51

Kelkar, H.S., Shankar, V., Deshpande, M.V. (1990), Rapid isolation and regeneration of Sclerotium rolfsii protoplasts and their potential application for starch hydrolysis. Enzyme Microb. Technol., 12, 510-514

Keller, U., Pöschmann, S., Krengel, U., Kleinkauf, H., Kraepelin, G. (1983), Studies on protoplast fusion in Streptomyces chrysomallus. J. Gen. Microbiol., 129, 1725-1731

Kim, B.K., Kang, J.H., Kim, H.W., Shim, M.J., Choi, E.C. (2000), Mycelial protoplasts isolation and regeneration of Lentinus lepideus. Life Sci., 66, 13591367

Kolar, H., Mischak, H., Kammel, W.P., Kubicek, C.P. (1985), Carboxymethylcellulase and b-Glucosidase secretion by protoplasts of Trichoderma reesei. J. Gen. Microbiol., 131, 1339-1347

Kumari, J.A., Panda, T. (1992), Studies on critical analysis of factors influencing improved production off protoplasts from Trichoderma reesei micelium. Enzyme Microb. Technol., 14, 241-248

Laurila, H.O., Nevalainen, H., Mäkinen, V. (1985), Production of protoplasts from the fungi Curvularia inaequalis and Trichoderma reesei. Appl. Microbiol. Biotechnol., 21, 210-212

Lima, J.O., Santos, J.K., Pereira, J.F., Resende, M.L., Araújo, E.F., Queiroz, M.V. (2003), Development of a transformation system for Crinipellis perniciosa, the causal agent of witches' broom in cocoa plants. Curr. Genetics, 42, 236-240

Marx, D.H. (1969), The influence of ectotrophic mycorrhizal fungi on the resistance of pine roots to pathogenic infections. In. Antagonism of mycorrhizal fungi root pathogenic fungi and soil bacteria. Phytopatology, 5, 153-163

Meinhardt, L.W., Bellato, C.M., Tsai, S.M. (2001), The utilization of SYBR Green I to evaluate the nuclei number of fungal mycelia. Biotechniques, 31, $42-46$

Peberdy, J.F. (1989), Fungi without coats-protoplasts as tools for mycological research. Mycol. Res., 93, 1-20
Peberdy, J.F. (1991), Fungal protoplasts. In: Bennett, J.W., Lasure, L.L. (ed). More Gene Manipulations in Fungi, Academic Press New York, pp 307

Peberdy, J.F., Buckley, C.E., Daltrey, D.C., Moore, P.M. (1976), Factors affecting protoplast release in some filamentous fungi. Trans. Br. Mycol. Soc., 67, 23-26

Pereira, O.L., Kasuya, M.C.M., Borges, A.C., Araújo, E.F. (2005), Morphological and molecular characterization of mycorrhizal fungi isolated from neotropical orchids in Brazil. Can J. Botan., 83, 5465

Pereira, O.L., Rollemberg, C.L., Kasuya, M.C.M. (2003), Association des mycorhizies dans les orchidees - perspectives d'utilisation dans les programmes de propagation symbiotique. Orchidees, 55, 24-27

Peterson, R.L., Uetake, Y., Zelmer, C. (1998), Fungal symbioses with orchid protocorms (Review). Symbiosis, 25, 29-55

Royer, J.C., Hintz, W.E., Kerrigan, R.W., Horgen, P.A. (1992), Electrophoretic karyotype analysis of the button mushroom, Agaricus bisporus. Genome, 35, 694-698

Solís, S., Flores, M.E., Huitrón, C. (1996), Protoplasts from pectinolytic fungi: isolation, regeneration and pectinolytic enzyme production. Lett. Appl. Microbiol., 23, 36-42

Toyama, H., Yamaguchi, K., Shinmyo, A., Okada, H. (1984), Protoplast fusion of Trichoderma reesei, using immature conidia. Appl. Environ. Microbiol., 47, 363-368

Villanueva, J.R., Acha, I.G. (1971), Production and use of fungal protoplasts. In: Booth, C. (ed). Methods in Microbiology, Academic Press London and New York, pp. 665

Yan, P.S., Jiang, J.H., Cui, W.S. (2004), Characterization of protoplasts prepared from the edible fungus, Stropharia rugoso-annulata. World J. Microbiol. Biotechnol., 20, 173-177

Yang, H.A., Sivasithamparam, K., O'Brien, P.A. (1993), Improved method for protoplast regeneration of Rhizoctonia solani. Soil Biol. Biochem., 25, 633636

Zettler, L.W. (1997), Orchid-fungal symbiosis and its value in conservation. McIvainea, 13, 40-45

Zettler, L.W., Burkhead, J.C., Marshall, J.A. (1999), Use of a mycorrhizal fungus from Epidendrum conopseum to germinate seed of Encyclia tampensis in vitro. Lindleyana, 14, 102-105

Zettler, L.W., Sunley, J.A., Delaney, T.W. (2000), Symbiotic seed germination of an orchid in decline (Platanthera integra) from the Green Swamp, North Carolina. Castanea, 65, 207-212

Received: July11, 2007; Revised: March 24, 2008; Accepted: April 17, 2009. 